\title{
Recent advances in the molecular mechanism of
}

\section{mitochondrial calcium uptake [version 1; peer review: 4}

\section{approved]}

\author{
Giorgia Pallafacchina1,2, Sofia Zanin³, Rosario Rizzuto1 \\ ${ }^{1}$ Department of Biomedical Sciences, University of Padua, Padua, 35131, Italy \\ 2Italian National Research Council (CNR), Neuroscience Institute, Padua, 35131, Italy \\ ${ }^{3}$ Department of Medicine, University of Padua, Padua, 35128, Italy
}

V1 First published: 28 Nov 2018, 7(F1000 Faculty Rev):1858

https://doi.org/10.12688/f1000research.15723.1

Latest published: 28 Nov 2018, 7(F1000 Faculty Rev):1858

https://doi.org/10.12688/f1000research.15723.1

\section{Abstract}

In the last few decades, a large body of experimental evidence has highlighted the complex role for mitochondria in eukaryotic cells: they are not only the site of aerobic metabolism (thus providing most of the ATP supply for endergonic processes) but also a crucial checkpoint of cell death processes (both necrosis and apoptosis) and autophagy. For this purpose, mitochondria must receive and decode the wide variety of physiological and pathological stimuli impacting on the cell. The "old" notion that mitochondria possess a sophisticated machinery for accumulating and releasing $\mathrm{Ca}^{2+}$, the most common and versatile second messenger of eukaryotic cells, is thus no surprise. What may be surprising is that the identification of the molecules involved in mitochondrial $\mathrm{Ca}^{2+}$ transport occurred only in the last decade for both the influx (the mitochondrial $\mathrm{Ca}^{2+}$ uniporter, $\mathrm{MCU}$ ) and the efflux (the sodium calcium exchanger, NCX) pathways. In this review, we will focus on the description of the amazing molecular complexity of the MCU complex, highlighting the numerous functional implications of the tissue-specific expression of the variants of the channel pore components (MCU/MCUb) and of the associated proteins (MICU 1, 2, and 3, EMRE, and MCUR1).

\section{Keywords}

Mitochondria, mitochondrial $\mathrm{Ca} 2+$ uptake, mitochondrial ion transport, MCU, MICU

\section{Open Peer Review}

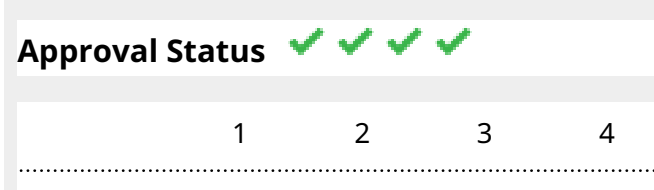

version 1

28 Nov 2018

Faculty Reviews are review articles written by the prestigious Members of Faculty Opinions. The articles are commissioned and peer reviewed before publication to ensure that the final, published version is comprehensive and accessible. The reviewers who approved the final version are listed with their names and affiliations.

1. Roberto Docampo, University of Georgia, Athens, USA

2. Israel Sekler, Ben-Gurion University, BeerSheva, Israel

3. Evgeny V Pavlov, New York University, 345

East 24th Street, New York, USA

4. Dipayan Chaudhuri, University of Utah, Salt Lake City, USA

Any comments on the article can be found at the end of the article. 
Corresponding authors: Giorgia Pallafacchina (giorgia.pallafacchina@unipd.it), Rosario Rizzuto (rosario.rizzuto@unipd.it)

Author roles: Pallafacchina G: Writing - Original Draft Preparation; Zanin S: Writing - Original Draft Preparation; Rizzuto R: Writing Review \& Editing

Competing interests: No competing interests were disclosed.

Grant information: This work was supported by grants to Rosario Rizzuto from the Italian Ministries of Health (Ricerca Finalizzata.) and of Education, University and Research (FIRB), the European Union (ERC mitoCalcium, no. 294777), the National Institutes of Health (grant \#1P01AG025532-01A1), the Italian Association for Cancer Research (AIRC IG18633), and Telethon-Italy (GGP16029).

Copyright: ( 2018 Pallafacchina $\mathrm{G}$ et al. This is an open access article distributed under the terms of the Creative Commons Attribution License, which permits unrestricted use, distribution, and reproduction in any medium, provided the original work is properly cited.

How to cite this article: Pallafacchina G, Zanin S and Rizzuto R. Recent advances in the molecular mechanism of mitochondrial calcium uptake [version 1; peer review: 4 approved] F1000Research 2018, 7(F1000 Faculty Rev):1858

https://doi.org/10.12688/f1000research.15723.1

First published: 28 Nov 2018, 7(F1000 Faculty Rev):1858 https://doi.org/10.12688/f1 000research.15723.1 


\section{Introduction}

$\mathrm{Ca}^{2+}$ is universally recognised as one of the most pleiotropic second messengers in cell biology. Indeed, $\mathrm{Ca}^{2+}$ ions are responsible for decoding a variety of extracellular and intracellular stimuli, which, in animals, range from endocrine secretion to gene expression, muscle contraction, and synaptic transmission ${ }^{1-5}$. The efficacy of $\mathrm{Ca}^{2+}$ as a signalling molecule relies mainly on the maintenance of a steep $\mathrm{Ca}^{2+}$ gradient between the concentration in the extracellular (few $\mathrm{mM})$ and intracellular $(\sim 100 \mathrm{nM})$ environments. This $>10,000$-fold difference ensures that even very small changes in intracellular $\mathrm{Ca}^{2+}$ concentration $\left(\left[\mathrm{Ca}^{2+}\right]_{\mathrm{i}}\right)$ are effective in regulating the numerous $\mathrm{Ca}^{2+}$-sensitive proteins of the cell, such as catalytic enzymes, channels, and transcription factors ${ }^{6}$. The maintenance of a low $\left[\mathrm{Ca}^{2+}\right]_{i}$ is tightly controlled by the presence of pumps and transporters both at the plasma membrane $^{7}$ and at the membrane of organelles accumulating large amounts of $\mathrm{Ca}^{2+8,9}$. The endoplasmic/sarcoplasmic reticulum (ER or SR in striated muscle) is undoubtedly the main intracellular $\mathrm{Ca}^{2+}$ store; nevertheless, other cellular compartments actively participate in modulating $\left[\mathrm{Ca}^{2+}\right]_{\mathrm{i}}$ : first of all mitochondria but also the Golgi apparatus ${ }^{10}$, endosomes, and lysosomes ${ }^{2,5,11}$.
The role for mitochondria in $\mathrm{Ca}^{2+}$ handling was first demonstrated in the 1960's, when their ability to actively accumulate $\mathrm{Ca}^{2+}$ was evaluated in different cellular ex vivo models ${ }^{12-14}$. This occurred even before the advent of the chemiosmotic theory ${ }^{15}$, which provided the thermodynamic basis for $\mathrm{Ca}^{2+}$ entry into mitochondria. In addition, the role for mitochondria in cell function has gradually expanded, and its initial identification as the powerhouse for cellular energy supply was subsequently integrated into a more complex activity that includes the regulation of cell death, metabolism, and signalling pathways ${ }^{16-18}$. Notably, many mitochondrial functions are directly regulated by the level of $\mathrm{Ca}^{2+}$ ions inside the organelles ${ }^{4,19}$. The control of mitochondrial $\mathrm{Ca}^{2+}$ concentration $\left(\left[\mathrm{Ca}^{2+}\right]_{\mathrm{mt}}\right)$ is thus of primary relevance for cell physiology, and emerging evidence converges on the concept that its dysregulation is of utmost importance in the establishment of pathological conditions.

In this commentary, we will focus on the molecular machinery underlying mitochondrial $\mathrm{Ca}^{2+}$ uptake, the mitochondrial $\mathrm{Ca}^{2+}$ uniporter (MCU) complex (see Figure 1), to which our laboratory has dedicated much effort in the last decade, contributing to its

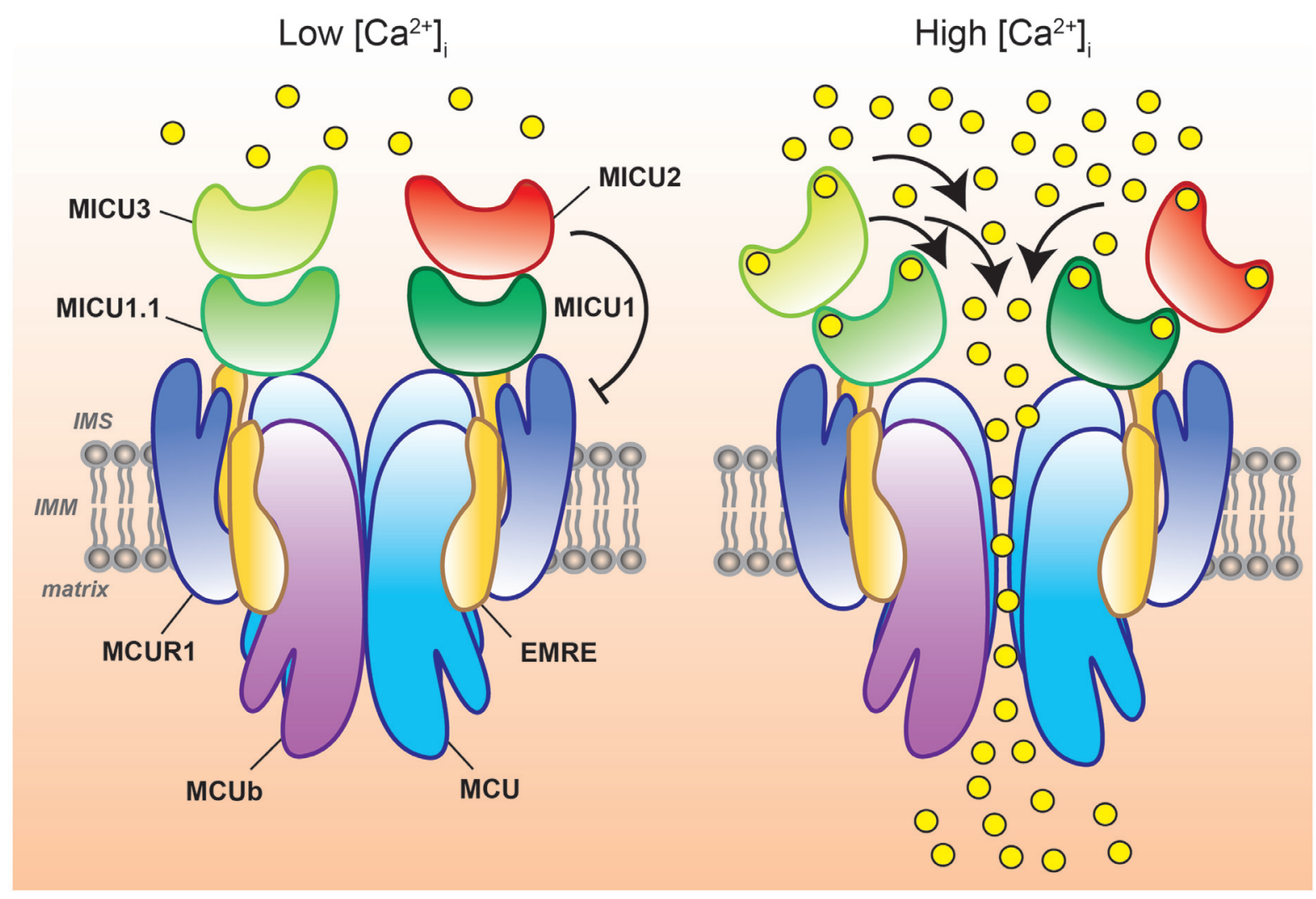

Figure 1. The mitochondrial calcium uniporter (MCU) complex. Schematic representation of MCU-mediated $\mathrm{Ca}^{2+}$ entry into mitochondria at different intracellular $\mathrm{Ca}^{2+}$ concentrations $\left(\left[\mathrm{Ca}^{2+}\right]_{\mathrm{i}}\right)$. Mitochondrial $\mathrm{Ca}^{2+}$ uptake is controlled by a multiprotein complex consisting of $\mathrm{MCU}$ and MCUb (the pore-forming subunits) together with the essential mitochondrial $\mathrm{Ca}^{2+}$ uniporter regulator (EMRE), the mitochondrial $\mathrm{Ca}^{2+}$ uptake (MICU) proteins, MICU1, MICU1.1, MICU2, and MICU3, and, possibly, the MCU regulator 1 (MCUR1). At low [Ca ${ }^{2+}$;, MICU1/MICU1.1-MICU2 or MICU1/MICU1.1-MICU3 heterodimers ensure MCU gatekeeper activity, preventing undesirable mitochondrial $\mathrm{Ca}^{2+} \mathrm{Cycling}^{2}$ in resting cells. At high $\left[\mathrm{Ca}^{2+}\right]$; the MICU proteins act as positive regulators of MCU channel activity, allowing efficient mitochondrial $\mathrm{Ca}^{2+}$ uptake (right). IMS, intermembrane space; IMM, inner mitochondrial membrane. 
discovery in 2011 and unravelling its molecular complexity and functional significance.

\section{The mitochondrial $\mathrm{Ca}^{2+}$ uniporter complex}

Since the first reports of mitochondrial $\mathrm{Ca}^{2+}$ uptake ${ }^{12-14}$, extensive studies have been conducted to identify the mitochondrial $\mathrm{Ca}^{2+}$ entry mechanism, characterised by Ruthenium Red sensitivity, high selectivity, and high capacity for the cation ${ }^{20}$. Only from 2010 , with the identification of the first regulator of the mitochondrial $\mathrm{Ca}^{2+}$ channel, the mitochondrial $\mathrm{Ca}^{2+}$ uptake protein 1 (MICU1) ${ }^{21}$, and, one year after, by the cloning and molecular characterisation of the gene coding for the $\mathrm{MCU}^{22,23}$, the entry pathway was characterised at the molecular level and the route for the genetic manipulation of mitochondrial $\mathrm{Ca}^{2+}$ uptake was finally open.

\section{The mitochondrial $\mathrm{Ca}^{2+}$ uniporter $\mathrm{MCU}$}

In 2011, two independent in silico screenings ${ }^{22,23}$ identified the CCDC109a gene product as the long-sought pore-forming unit of the MCU channel mediating mitochondrial $\mathrm{Ca}^{2+}$ uptake in mammalian cells. Purified MCU protein reconstitution in lipid bilayers revealed a $\mathrm{Ca}^{2+}$ channel activity with the electrophysiological features of the hypothetical $\mathrm{MCU}^{20}$. In addition, it was clearly shown that MCU downregulation in mammalian cells inhibits mitochondrial $\mathrm{Ca}^{2+}$ uptake while its overexpression increases mitochondrial $\mathrm{Ca}^{2+}$ accumulation, thus proving that it is bona fide the channel mediating $\mathrm{Ca}^{2+}$ uptake in mitochondria ${ }^{23}$.

The sequence of MCU consists of two transmembrane $\alpha$-helix domains spanning the inner mitochondrial membrane (IMM), the second of which contains the critical DIME motif responsible for the channel selectivity filter, linked by a short loop toward the mitochondrial intermembrane space (IMS), while both the $\mathrm{C}$ - and the N-termini face the mitochondrial matrix ${ }^{22,24}$. A single MCU molecule per se is thus not able to form the channel but should organise in oligomers, and MCU was initially proposed to arrange itself into tetramers ${ }^{25}$. This hypothesis was very recently confirmed by coherent high-resolution cryo-EM data from four independent groups on different MCU orthologs s $^{2426-28}$. These seminal studies finally unveiled the structure and arrangement of MCU protomers within the complex and the exact position of the channel selectivity filter. The 3D reconstruction of EM data unambiguously revealed that MCU forms tetramers with a nonobvious symmetry: the transmembrane domain displays a fourfold symmetry, while the N-terminal domain (NTD) on the matrix side shows a twofold symmetry axis. These findings confuted the pentameric MCU architecture that was previously proposed based on magnetic resonance and negative staining EM data from Caenorhabditis elegans MCU- $\mathrm{NTD}$ protein, in which a significant portion of the NTD was removed to facilitate the analysis $^{29}$. In addition, the MCU DIME motif, which contains the two critical acidic residues directly involved in the cation coordination, has now been shown to reside at the beginning of - and thus integral to - the second transmembrane helix (TMH), and not in the loop connecting the two transmembrane helices, as previously suggested ${ }^{29}$.

However, as Raffaello et al. showed, MCU is not the only pore-forming unit of the oligomer, but it associates with the protein encoded by the MCU paralog gene CCDC109b, which was thus named $\mathrm{MCUb}^{25}$. The characterisation of MCUb demonstrated that it acts as a negative regulator of MCU activity both in lipid bilayer experiments and when overexpressed in mammalian cells ${ }^{25}$ (see Figure 1). To note, in other organisms, such as Trypanosoma cruzi, the ortholog of $\mathrm{MCUb}$ acts as a $\mathrm{Ca}^{2+}$ conducting subunit and its overexpression enhances, rather than dampens, mitochondrial $\mathrm{Ca}^{2+}$ uptake $^{30}$. Interestingly, in another trypanosomatid, Trypanosoma brucei, two additional MCU isoforms were identified, MCUc and MCUd, which are also endowed with $\mathrm{Ca}^{2+}$ uniporter activity and are able to form heterotetrameric complexes with their homologues MCU and MCUb ${ }^{31}$. This highlights the existence of significant species-specific differences in the function and distribution of MCU orthologues, despite their sequence conservation, and this should be taken into account when studying different organisms. Moreover, the expression and relative proportion of MCU and MCUb vary significantly among different tissues in mammals; thus, each cell type may have different variants of the uniporter owing to the specific composition and stoichiometry of MCU subunits. This accounts for tissue-specific variations of the capacity of mitochondria to take up $\mathrm{Ca}^{2+}$ and perfectly fits with the electrophysiological recordings of MCU $\mathrm{Ca}^{2+}$ currents in mitochondria from different mammalian tissues ${ }^{32}$. In skeletal muscle, for example, the presence of a high MCU:MCUb ratio ${ }^{25}$ matches the highest mitochondrial $\mathrm{Ca}^{2+}$ conductance recorded in this tissue ${ }^{32}$, whereas, in adult heart, the relatively elevated MCUb expression ${ }^{25}$ results in a considerably low $\mathrm{Ca}^{2+}$ current in cardiomyocyte mitochondria ${ }^{32}$. In cardiac cells, in which $\sim 37 \%$ of the volume is occupied by mitochondria ${ }^{33}$, this is crucial for preventing massive mitochondrial $\mathrm{Ca}^{2+}$ accumulation that would potentially cause undesired buffering of the $\left[\mathrm{Ca}^{2+}\right]_{i}$ transients required for contraction, futile cycling of $\mathrm{Ca}^{2+}$ across the IMM, and, eventually, organelle $\mathrm{Ca}^{2+}$ overload and apoptosis. The control of the MCU:MCUb proportion in the mitochondrial $\mathrm{Ca}^{2+}$ channel pore domain is thus fundamental for the function and physiology of different tissues.

After the molecular identification of the MCU pore components and auxiliary factors, the path for the genetic manipulation of mitochondrial $\mathrm{Ca}^{2+}$ uptake machinery in cells and animal models was finally opened. The first $M C U^{--}$mouse was generated by Finkel's group in 2013. It shows a relatively mild phenotype, and, despite the expected abrogation of mitochondrial $\mathrm{Ca}^{2+}$ uptake, it develops normally and displays unaffected basal metabolism ${ }^{34}$. However, the $\mathrm{MCU}^{-1-}$ mouse shows increased plasma lactate levels after starvation and impaired exercise performance accompanied by a reduction in the activity of pyruvate dehydrogenase in skeletal muscle ${ }^{34}$. These findings, together with the fact that $\mathrm{MCU}^{-/-}$ mouse survival depends on the genetic background ( $M C U$ deletion is embryonically lethal in a pure C57/BL6 background ${ }^{35}$ ), pointed to a more subtle and less obvious involvement of mitochondrial $\mathrm{Ca}^{2+}$ uptake in organ metabolism and organism development. This issue has been elegantly addressed by recent studies implementing tissue-specific modulation of MCU expression (by ablation/downregulation or overexpression) in adult tissues. For example, cardiac-specific tamoxifen-inducible $M C U$ deletion in adult mice, differently from the germline genetic ablation of $M C U$, which did not protect from ischemic-reperfusion injury ${ }^{34}$, clearly protects from ischemia-reperfusion heart damage, abrogates the contractile responsiveness to $\beta$-adrenergic stimulation responsible for the so-called "fight-or-flight" response, and reduces 
heart bioenergetics reserve capacity, even though it does not induce phenotypic abnormalities either in basal conditions or after cardiac overload and does not alter cardiomyocytes' resting $\left[\mathrm{Ca}^{2+}\right]_{\mathrm{mt}}{ }^{36-39}$. These results suggest that MCU may be dispensable for cardiac homeostasis in basal conditions, while it appears to play a major role in cardiac metabolic flexibility during acute stress. Similarly to what has been reported for the heart tissue, germline deletion of $M C U$ did not protect from hypoxic/ischemic brain injury ${ }^{40}$. However, brains from conditional neuronal-specific inducible $M C U$-deleted mice as well as primary cortical neurons silenced for $M C U$ show a significant reduction of the hypoxic/ ischemic damage and decreased cell death without impairment of neuronal mitochondria metabolism ${ }^{41}$. Once more, these findings point to the existence of a strong drive for organs and tissues to respond to chronic $M C U$ ablation by establishing adaptive metabolic shunts in order to cope with/bypass impaired mitochondrial $\mathrm{Ca}^{2+}$ signalling. Such adaptation to mitochondria dysfunction has also been described in the cardiac-specific $\mathrm{Tfam}^{-/}$mouse, the murine model for human cardiomyopathies with mtDNA depletion $^{42}$, in which the alteration in mitochondrial metabolism due to oxidative phosphorylation (OXPHOS) deficiency induces a secondary upregulation of MCU protein and a concomitant downregulation of $N C L X$ transcription ${ }^{43}$. The resulting increased mitochondrial $\mathrm{Ca}^{2+}$ uptake and reduced $\mathrm{Ca}^{2+}$ efflux in $\mathrm{Tfam}^{-/}$ cardiac mitochondria, although inducing an elevated and potentially damaging $\left[\mathrm{Ca}^{2+}\right]_{\mathrm{m}}$, appear somehow functional to ensure an efficient $\mathrm{Ca}^{2+}$-dependent mitochondrial respiration that otherwise would be compromised by the pathology ${ }^{41}$.
Overall, these findings lead us to the following consideration: experimental systems featuring long-term genetic manipulation of the mitochondrial $\mathrm{Ca}^{2+}$ uptake machinery should be evaluated with caution, and the potential induction of unpredicted phenotypes, as a consequence of adaptive/maladaptive responses, should be taken into account. This is particularly relevant when in vivo models are considered.

In line with this, the acute but transient manipulation of MCU expression in skeletal muscle provided additional intriguing evidence of the wide-ranging influence of mitochondrial $\mathrm{Ca}^{2+}$ signalling in the maintenance of organ and organism homeostasis. The decrease or enhancement of $\left[\mathrm{Ca}^{2+}\right]_{\mathrm{mt}}$ by AAV-mediated MCU silencing or overexpression, respectively, demonstrated that mitochondrial $\mathrm{Ca}^{2+}$ uptake regulates myofibre trophism through the modulation of the activity of the insulin growth factor-1/Akt pathway and the transcription of the peroxisome proliferatoractivated receptor gamma coactivator 1 alpha 4 gene (PGCl $\alpha 4)$. In particular, the overexpression of $\mathrm{MCU}$ in both adult and neonatal muscles induces significant fibre hypertrophy, which is not accompanied by alterations in mitochondrial membrane potential or other metabolic parameters (such as glycogen content and succinate dehydrogenase activity $)^{44}$. On the contrary, MCU downregulation leads to marked fibre atrophy as demonstrated by reduction of fibre size, inhibition of Akt activity, reduction of PGCl $\alpha 4$ transcripts, and impaired activation of the pyruvate dehydrogenase complex ${ }^{44}$, in agreement with the data from the $M C U^{-1-}$ mice $^{34}$ (see Figure 2).

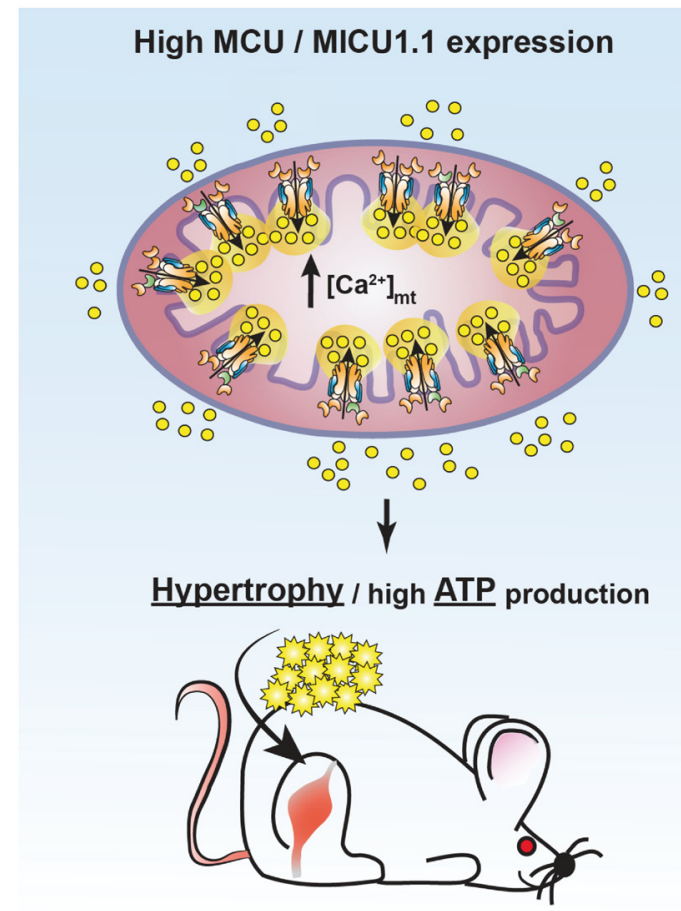

\section{Low MCU / MICU1.1 expression}

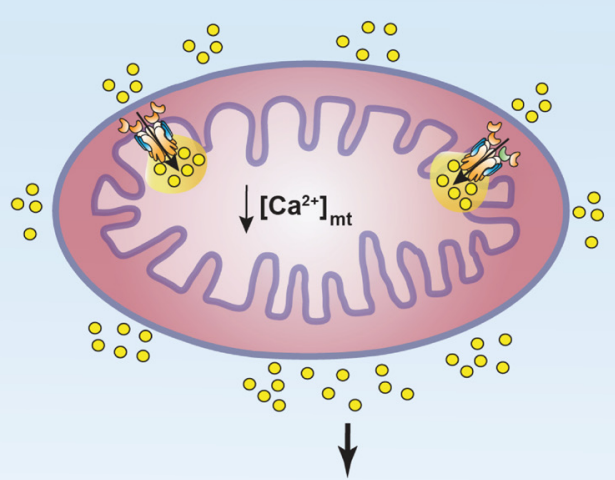

Atrophy / reduced ATP production

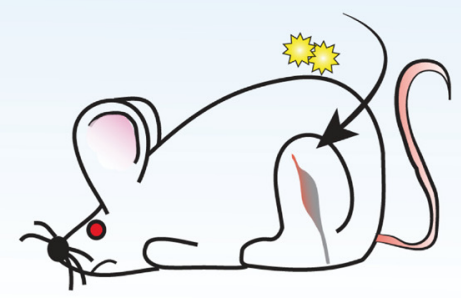

Figure 2. The role of mitochondrial $\mathrm{Ca}^{2+}$ signalling in skeletal muscle trophism. Schematic representation of the effects of manipulating mitochondrial $\mathrm{Ca}^{2+}$ uptake in skeletal muscle fibres. Increased mitochondrial $\mathrm{Ca}^{2+}$ accumulation by enhanced expression of mitochondrial $\mathrm{Ca}^{2+}$ uniporter (MCU) or mitochondrial $\mathrm{Ca}^{2+}$ uptake protein 1.1 (MICU1.1) leads to muscle hypertrophy by stimulating fibre growth and ATP production (left). Reduction of mitochondrial $\mathrm{Ca}^{2+}$ uptake by downregulation of either MCU or MICU1.1 causes fibre atrophy and impaired ATP production (right). $\left[\mathrm{Ca}^{2+}\right]_{\mathrm{mt}}$, mitochondrial $\mathrm{Ca}^{2+}$ concentration. 
Moreover, the recent description of a mouse model bearing constitutive skeletal muscle-specific deletion of MCU $\left(s k M C U^{--}\right.$mice) has been fundamental to uncover the metabolic rewiring occurring at the level of skeletal muscle cell but also, importantly, systemically ${ }^{45}$. In line with previous data ${ }^{34,44}$, the muscle of $s k M C U^{-1-}$ mice shows decreased performance and smaller fibre size compared to that of control mice ${ }^{45}$. Moreover, it shows a shift toward fast fibre type and an enhanced preference for fatty acid oxidative metabolism ${ }^{45}$. Interestingly, the ablation of $M C U$ in skeletal muscle also impinges on other tissues, as shown by the increased catabolic response in both liver and adipose tissue of $s k M C U^{-1}$ animals ${ }^{45}$. This clearly points out how the mitochondrial metabolic adaptation in response to altered $\mathrm{Ca}^{2+}$ dynamics (i.e. $M C U$ deletion) within the muscle tissue may have major systemic impact on different tissues and, importantly, on the modulation of global metabolism.

\section{The MICU proteins}

MICU1 was the first regulator of mitochondrial $\mathrm{Ca}^{2+}$ uptake to be identified ${ }^{21}$, even before the identification of MCU itself. It was initially described as an EF-hand $\mathrm{Ca}^{2+}$-binding protein associated with the IMM that stimulates MCU channel opening and thus acts as a positive modulator of mitochondrial $\mathrm{Ca}^{2+}$ uptake. Subsequent findings defined the crucial role of MICU1 in keeping the channel inactive under resting conditions, i.e. at low $\left[\mathrm{Ca}^{2+}\right]_{i}^{46,47}$, thus preventing massive $\mathrm{Ca}^{2+}$ entry that will otherwise cross the IMM down the steep electrochemical gradient and cause harmful mitochondrial $\mathrm{Ca}^{2+}$ overload. MICU1 was thus appropriately defined as the gatekeeper of the MCU channel. This concept has been recently confirmed by two independent in vivo $M I C U 1^{-/-}$ mouse models. These $M I C U 1^{-/}$animals, despite normal embryonic development and growth, show a variable degree of postnatal lethality (one out of six to one out of seven surviving pups in the case of CRISPR/Cas9 mutants ${ }^{48}$ and $100 \%$ lethality in the case of Cre recombinase/LoxP deleted alleles ${ }^{49}$ ) mostly due to breathing failure for the underdevelopment of the respiration coordination centres (cerebellum and Purkinje cells) ${ }^{49}$. The few surviving knockout mice display muscle impairment and ataxia $^{48}$, a phenotype very similar to that described in children with a MICU1 mutation $^{50}$. The analysis of $\mathrm{MICU1}^{-/-}$mitochondria revealed increased matrix $\left[\mathrm{Ca}^{2+}\right]_{\mathrm{mt}}$, increased sensitivity to permeability transition pore (PTP) opening and cell death, and reduced production of ATP, similar to what was reported in MICU1-silenced hepatocytes and Hela cells ${ }^{46,47}$. Overall, these data clearly highlight the relevance of MICU1 gatekeeping function in the control of mitochondrial $\mathrm{Ca}^{2+}$ homeostasis and metabolism. Nevertheless, an additional intriguing feature of MICU1 action has recently emerged, which consists of its ability to confer MCU selectivity for $\mathrm{Ca}^{2+}$ over $\mathrm{Mn}^{2+}$. Indeed, the DIME motif in the MCU pore subunit appears to be unable per se to discriminate between $\mathrm{Ca}^{2+}$ and $\mathrm{Mn}^{2+}$ in the absence of MICU1 ${ }^{51}$. However, when present, MICU1 prevents $\mathrm{Mn}^{2+}$ entry in mitochondria, thus ensuring the stringent $\mathrm{Ca}^{2+}$ selectivity of $\mathrm{MCU}^{51}$. In this scenario, the proper stoichiometry of MICU1 is thus crucial to avoid mitochondrial $\mathrm{Mn}^{2+}$ uptake and to prevent $\mathrm{Mn}^{2+}$ toxicity. This concept may have relevant implications for human pathologies, especially for those diseases caused by MICU1 deficiency ${ }^{50,52,53}$ but also for Parkinson's disease, as already suggested ${ }^{51}$.
Additional MICU family members have been identified by genome sequence analysis soon after MICU1, namely MICU2 (EFHA1) and MICU3 (EFHA2) ${ }^{54}$, which share $41 \%$ and $34 \%$ identity with MICU1, respectively, but display a broad and nonoverlapping expression pattern compared to MICU $1^{55}$. In particular, MICU2 was shown to bind covalently to MICU1 through disulphide bridges, and the resulting dimer endows the genuine MCU gatekeeper activity ${ }^{56}$. In this scenario, cytosolic $\mathrm{Ca}^{2+}$ elevation causes $\mathrm{Ca}^{2+}$ binding to the EF-hand domains of the MICU1-MICU2 dimer, allowing MICU1 to function as a positive regulator of MCU activity, thus efficiently promoting $\mathrm{Ca}^{2+}$ entry into the organelle ${ }^{56}$ (see Figure 1).

As for MICU3, its evolutionary conservation and sequence similarity to MICU1 suggested that it may share a common biological function with MICU1 $1^{54}$. Along this line, its role as a positive regulator of mitochondrial $\mathrm{Ca}^{2+}$ uptake has been demonstrated recently ${ }^{55}$. Indeed, the expression of MICU3 in Hela cells, which normally do not express it, showed that it interacts with MICU1, but not with MICU2, forming obligatory dimers ${ }^{55}$ (see Figure 1). This interaction causes a significant increase of mitochondrial $\mathrm{Ca}^{2+}$ uptake, demonstrating the stimulatory action of MICU3 on MCU activity. In addition, while displaying a reduced gatekeeper activity, MICU3 has been shown to mediate a more rapid response of mitochondria to $\left[\mathrm{Ca}^{2+}\right]_{\mathrm{i}}$ changes, allowing a shorter delay between the $\left[\mathrm{Ca}^{2+}\right]_{i}$ rise and the increase in mitochondria $\mathrm{Ca}^{2+}$ uptake compared to MICU1 ${ }^{55}$. MICU3 thus plays a pivotal role in determining the kinetics of mitochondrial $\mathrm{Ca}^{2+}$ signalling and consequently in the modulation of global $\left[\mathrm{Ca}^{2+}\right]_{\mathrm{i}}$ dynamics, which may be of utmost relevance for the decoding of $\mathrm{Ca}^{2+}$ signals in excitable cells, such as neurons, where indeed MICU3 shows the highest level of expression ${ }^{54,55}$.

By the interaction of monomers with non-overlapping functions, the MICU proteins confer an important property of the mitochondrial $\mathrm{Ca}^{2+}$ uptake system: the sigmoidicity of the dose-response to $\mathrm{Ca}^{2+}$. Indeed, the activity of $\mathrm{MCU}$, which is kept low at resting $\left[\mathrm{Ca}^{2+}\right]_{\mathrm{i}}(\sim 100 \mathrm{nM})$ owing to the MICU1-MICU2 gatekeeper action, as already discussed, becomes extremely efficient upon $\left[\mathrm{Ca}^{2+}\right]_{\mathrm{i}}$ elevation. Indeed, $\mathrm{Ca}^{2+}$ binding to the MICU1-MICU2 regulatory complex converts it from an inhibitory regulator (ensuring gatekeeping) at basal $\left[\mathrm{Ca}^{2+}\right]_{\mathrm{i}}$ to an activator, strongly enhancing the flux through the channel. The threshold for MCU activation is directly dependent on the $\mathrm{Ca}^{2+}$ affinity of MICUs' EF hands (which range from $300 \mathrm{nM}$ to $1.3 \mu \mathrm{M}$ ), since the cooperative $\mathrm{Ca}^{2+}$ binding to these domains induces a conformational change in the MICU1-MICU2 dimer, which acts as a molecular switch relieving MCU inhibition ${ }^{57}$.

Despite the role for MICU2 in the regulation of $\mathrm{MCU}$ gatekeeping and activation being controversial still, an intriguing hypothesis is that it has evolved to spatially restrict the $\mathrm{Ca}^{2+}$ crosstalk between single inositol trisphosphate receptor (IP3R) and MCU channels ${ }^{58}$. Indeed, the presence of MICU2 has been shown to decrease the $\mathrm{Ca}^{2+}$ affinity of the MICU1 gatekeeper, thus elevating the threshold for MCU opening ${ }^{58}$. In the context of the intracellular environment, this increased threshold for mitochondrial $\mathrm{Ca}^{2+}$ uptake translates into the need for a shorter 
distance between the ER $\mathrm{Ca}^{2+}$-releasing channel (IP3R) and the mitochondrial $\mathrm{Ca}^{2+}$ uptake channel (MCU) ${ }^{58}$.

In line with this, in the last few years, the stoichiometry of MCU components has emerged as a crucial feature of the modulation of mitochondrial $\mathrm{Ca}^{2+}$ uptake rate. The relative proportion of the MICU proteins, in particular, has been demonstrated as the basis of the tissue-specific differences in cellular $\mathrm{Ca}^{2+}$ dynamics ${ }^{59}$. Indeed, the different ratio of MICU1:MCU and MICU1:MICU2 proteins in the liver, the heart, and skeletal muscle has been correlated with the distinct mitochondrial $\mathrm{Ca}^{2+}$ handling of these three tissues ${ }^{59}$. The level of MICU1 expression, which is much lower in cardiac tissue (while MCU and MICU2 are present at similar levels) compared to liver, has been suggested to determine the lower maximal $\mathrm{Ca}^{2+}$ uptake capacity and less-steep $\mathrm{Ca}^{2+}$ dependence that characterise cardiac mitochondria compared to liver mitochondria, as electrophysiological data ${ }^{32}$ and intracellular $\mathrm{Ca}^{2+}$ measurements ${ }^{59}$ revealed. The low amount of MICU1 in cardiac mitochondria is instrumental to reduce mitochondrial $\mathrm{Ca}^{2+}$ uptake upon cytosolic $\mathrm{Ca}^{2+}$ elevation, allowing the decoding of the repetitive cytosolic $\mathrm{Ca}^{2+}$ spikes of the beating heart into a graded increase of matrix $\mathrm{Ca}^{2+}$. This integration of frequency fluctuations is crucial to prevent mitochondrial $\mathrm{Ca}^{2+}$ overload, which will be otherwise detrimental to the cardiac myocytes. By contrast, the relatively high MICU1 level and its cooperative activation of MCU in hepatocytes ensure the punctual and massive mitochondrial $\mathrm{Ca}^{2+}$ increase at every single cytosolic $\mathrm{Ca}^{2+}$ spike ${ }^{59}$, which is functional to liver oxidative metabolism.

An additional degree of complexity came with the discovery of an alternative MICU1 isoform, extremely conserved and expressed at the highest level in skeletal muscle, which originates from the alternative splicing of the MICU1 mRNA, the MICU1.1 splice variant ${ }^{60}$ (see Figure 1). This alternative isoform was shown to dimerise with MICU2, showing gatekeeper activity similar to that of MICU1, but it binds $\mathrm{Ca}^{2+}$ one order of magnitude more efficiently than MICU1 and activates MCU at lower $\left[\mathrm{Ca}^{2+}\right]_{\mathrm{i}}$ than MICU1 ${ }^{60}$. Thus, in skeletal muscle, the MICU1.1-MICU2 dimer ensures a much higher net $\mathrm{Ca}^{2+}$ entry and elevated ATP production than the MICU1-MICU2 dimer ${ }^{60}$. These results highlight a novel mechanism of the molecular plasticity of the MCU $\mathrm{Ca}^{2+}$ uptake machinery that allows skeletal muscle mitochondria to adapt to the intense metabolic challenge that characterises this tissue (see Figure 2).

The essential mitochondrial $\mathrm{Ca}^{2+}$ uniporter regulator EMRE To add further complexity to the study of MCU channel regulation, other molecules have been shown to interact with MCU in recent years. Indeed, the quantitative mass spectrometry analysis of the MCU-interacting proteins revealed the presence of a critical component of the MCU complex, the essential MCU regulator (EMRE) (see Figure 1), a $10 \mathrm{kDa}$ single-pass transmembrane protein that was proposed to be necessary for MCU function by bridging MCU interaction with MICU1 in mammalian cells ${ }^{61}$. Interestingly, EMRE appears to be required for MCU channel activity in metazoans only, since it is not found in plants, fungi, or protozoa, such as Dictyostelium discoideum, although they express MCU proteins with functional channel activity. While its exact role in the MCU complex is still uncertain, EMRE was proposed to mediate MCU sensitivity to matrix $\left[\mathrm{Ca}^{2+}\right]_{\mathrm{mt}}$, suggesting that MCU activity may be modulated by $\mathrm{Ca}^{2+}$ sensors facing both the IMS (MICUs) and the matrix (EMRE) ${ }^{62}$. However, this hypothesis was subsequently questioned by other groups, whose data supported an opposite topology for the EMRE protein, with the short $\mathrm{N}$-terminus exposed to the matrix while its acidic C-terminus faces the IMS ${ }^{63,64}$. In this conformation, EMRE action would be that of supporting MCU $\mathrm{Ca}^{2+}$ transport activity by interacting with the first TMH of MCU within the IMM and to interact also with MICU1 at the IMS via its C-terminus poly-aspartate tail, thus ensuring MICU1 binding to the channel and gatekeeping activity ${ }^{63}$.

Recently, the control of EMRE protein levels has emerged as a crucial aspect of MCU complex regulation. Indeed, a correct amount of EMRE is fundamental to guarantee the exact stoichiometry of the different MCU components. Alteration of EMRE protein levels by ablation of the AAA-proteases responsible for its degradation $^{65}$, or by expression of proteolytic-resistant EMRE constructs $^{62}$, leads to uncontrolled MCU channel opening causing mitochondrial $\mathrm{Ca}^{2+}$ leakage and mitochondrial $\mathrm{Ca}^{2+}$ overload, resulting in neuronal cell death ${ }^{65,66}$. The existence of a tight control of EMRE protein levels has also been demonstrated in vivo in the $M I C U 1^{--}$mice, where EMRE is reduced in a genetic condition characterised by increased $\left[\mathrm{Ca}^{2+}\right]_{\mathrm{mt}}$ basal levels ${ }^{48}$. These findings clearly underline a negative regulatory mechanism that keeps EMRE expression in check in order to cope with changes in MCU activity ${ }^{48}$.

The mitochondrial $\mathrm{Ca}^{2+}$ uniporter regulator $1 \mathrm{MCUR} 1$

Another protein that has been associated with the MCU complex $^{67,68}$, despite the original proteomic analysis of the MCU interactors failed to recover $\mathrm{it}^{61}$, is the MCU regulator 1 (MCUR1). MCUR1 is a coiled-coil-containing protein encoded by the CCDC90A gene initially identified by a RNAi screen searching for a mitochondrial membrane protein involved in $\mathrm{MCU}$ homeostasis ${ }^{67}$, whose precise function in the regulation of $\mathrm{MCU}$ activity and mitochondrial metabolism is still debated. Indeed, MCUR1 has been shown to be required for MCU-dependent $\mathrm{Ca}^{2+}$ uptake, since its knockdown dampens mitochondrial $\mathrm{Ca}^{2+}$ entry while its overexpression enhances $\mathrm{it}^{67}$. However, a direct action of MCUR1 on MCU activity was questioned by the finding that its silencing leads to a significant loss of mitochondrial membrane potential $\left(\Delta \Psi_{\mathrm{m}}\right)$, which per se can account for the decreased mitochondrial $\mathrm{Ca}^{2+}$ uptake ${ }^{69}$. In this context, MCUR1 has been suggested to act primarily as a cytochrome c oxidase (COX) assembly factor ${ }^{69}$, and this concept would also be supported by the fact that a MCUR1 orthologue is present in budding yeast ${ }^{70}$, which lack MCU, and is required for yeast COX activity and survival in non-fermentable medium ${ }^{69}$. Nevertheless, the patch clamp data of $\mathrm{Ca}^{2+}$ currents from voltage-clamped mitoplasts point to an effective role for the MCUR1 protein on MCU channel conductance, independently of $\Delta \Psi_{\mathrm{m}}{ }^{71}$. In line with this, experiments in Drosophila cells, which are resistant to $\mathrm{Ca}^{2+}$-induced mitochondrial permeability transition (MTP) $)^{72}$ and in which no MCUR1 homologs are found, show increased sensitivity to $\mathrm{Ca}^{2+}$-dependent PTP opening when heterologous human MCUR1 
is expressed, which is not accompanied by alterations in the rate of mitochondrial $\mathrm{Ca}^{2+}$ uptake ${ }^{72}$. Conversely, MCUR1 knockdown in mammalian cells renders them resistant to $\mathrm{Ca}^{2+}$ overload, providing protection from cell death ${ }^{72}$. This led the authors to conclude that MCUR1 regulates the $\mathrm{Ca}^{2+}$ threshold for the MPT and may act as a molecular bridge connecting the MCU channel to the MTP complex. Whether this hypothesis holds true still has to be tested.

More recently, the genetic deletion of MCUR1 in endothelial and cardiac tissues in vivo by mouse conditional knockout models $^{68}$ points to an involvement of MCUR1 in the assembly and function of the MCU channel. In particular, MCUR1 binding to MCU and EMRE appears to be necessary for MCU oligomerisation and stability, since $M C U R 1^{-/}$cells will display a significantly decreased amount of MCU-containing highmolecular-weight complexes and reduced rate of mitochondrial $\mathrm{Ca}^{2+}$ uptake $^{68}$. This, as expected, impinges on cellular energetics, as it is reflected by the dramatic reduction of ATP levels and consequent activation of the pro-survival autophagy pathway in cells depleted of MCUR $1^{72}$. Whether the pleiotropic roles for MCUR1 in the regulation of mitochondrial $\mathrm{Ca}^{2+}$ uptake, OXPHOS efficiency, and the apparent discordant phenotypes of MCUR1-depleted cells depend on the intrinsic transcriptional and metabolic differences of different cell types or on the speciesspecific features of the mitochondrial $\mathrm{Ca}^{2+}$ machinery is still an open question, and further investigation is needed to clarify it.

\section{The complexity of mitochondrial $\mathrm{Ca}^{2+}$ uptake regulation}

The regulation of the mitochondrial $\mathrm{Ca}^{2+}$ uptake machinery has been revealed to be far more complex than that resulting from just considering the cooperative actions of the different MCU components and their possible combinations. Indeed, the activity of the MCU channel relies on a multifaceted integration of regulatory mechanisms acting on both the MCU pore subunits and its co-regulators. Moreover, these mechanisms have been shown to occur at multiple levels-transcriptional, posttranscriptional, and post-translational—and their systematic identification has started to be accomplished only in recent years.

In neurons, for example, MCU transcription appears to be under the control of activity-dependent cytosolic $\mathrm{Ca}^{2+}$ signalling through the involvement of calmodulin $(\mathrm{CaM})$ and the activation of CaM-kinase $(\mathrm{CaMK})^{73}$. It has been shown that the immediateearly gene Npas4, a neuronal transcription factor with neuroprotective action against excitotoxicity ${ }^{74}$, acts directly downstream of the NMDAR signalling and of CaMK to modulate $M C U$ transcription $^{73}$. In another context, chromatin immunoprecipitation and promoter reporter analyses revealed that the $\mathrm{Ca}^{2+}$-regulated transcription factor cyclic adenosine monophosphate response element-binding protein (CREB) directly binds the MCU promoter and stimulates its transcriptional activity in chicken DT40 lymphocyte cells ${ }^{75}$. The CREB-mediated activity-dependent modulation of MCU expression in response to intracellular $\mathrm{Ca}^{2+}$ mobilisation via IP3R and store-operated
$\mathrm{Ca}^{2+}$ entry (SOCE) has also been proven to be crucial to ensure a prompt metabolic flexibility and cell survival in lymphocytes ${ }^{75}$.

The existence of post-transcriptional regulation of MCU has been initially described in cancer $^{76}$, where a strong inverse correlation between MCU expression level and the abundance of microRNA (miR)-25 has been reported in both tumour cell lines and colon adenocarcinoma samples ${ }^{76}$. Indeed, MCU expression is found to be upregulated in both colon and prostate cancer cells that show a reduced level of miR-25, and the overexpression of miR-25 in these cells downregulates MCU and increases cell sensitivity to apoptosis ${ }^{76}$. Similarly, in breast cancer, the downregulation of miR-340 is correlated with increased MCU expression in highly metastatic cells, while MCU targeting by miR-340 blocks the metabolic shift from OXPHOS to aerobic glycolysis that would otherwise favour cell migration and invasiveness ${ }^{77}$. In the context of pulmonary arterial hypertension $(\mathrm{PAH})$, in which vascular cells are hyper-proliferative and apoptosis resistant, exhibiting a cancer-like phenotype, the decreased MCU function that underlies the key phenotypic features of PAH (including elevation of $\left[\mathrm{Ca}^{2+}\right]_{\mathrm{i}}$, reduction of $\left[\mathrm{Ca}^{2+}\right]_{\mathrm{mt}}$, mitochondrial fragmentation, and the Warburg phenomenon) has been ascribed to the downregulation of MCU expression by both miR-25 and $\mathrm{miR}-138^{78}$. The overexpression of $\mathrm{MCU}$ or the blocking of the MCU-targeting miRs in PAH cells indeed restores $\mathrm{Ca}^{2+}$ dynamics, mitochondrial metabolism, and cell proliferation to physiological levels ${ }^{78}$. MiR-25 has also been shown to target and downregulate $\mathrm{MCU}$ in the heart, where it is suggested to protect myocytes from oxidative damage by reducing $\left[\mathrm{Ca}^{2+}\right]_{\mathrm{mt}}$ levels ${ }^{79}$. Another two muscle-specific miRNAs (myomiR), miR-1 and miR-206, have been implicated in the regulation of MCU expression in muscle ${ }^{80}$, of which miR-1 plays a major role in the context of cardiac development in both mice and humans. In mice, miR-1 upregulation is crucial during the first few postnatal weeks for the modulation of MCU activity in order to prevent massive $\left[\mathrm{Ca}^{2+}\right]_{\mathrm{mt}}$ elevation that would otherwise occur, since mitochondria distribution undergoes heavy remodelling at this time point and organelles are placed in close contact with the SR $\mathrm{Ca}^{2+}$-releasing channels ${ }^{80}$.

Post-translational modifications of MCU proteins have also been described. Indeed, the $\mathrm{Ca}^{2+}$-dependent tyrosine kinase Pyk2 has been shown to directly interact and phosphorylate MCU in cardiac cells in response to $\alpha$-adrenergic stimulation ${ }^{81}$. The MCU phosphorylation by Pyk2 has been proposed to promote its oligomerisation and to enhance mitochondrial $\mathrm{Ca}^{2+}$ entry, thus stimulating mitochondrial metabolism and favouring cytosolic $\mathrm{Ca}^{2+}$ clearance in cardiac cells ${ }^{81}$. In addition, the atomic resolution data of the N-terminus of MCU (residues 72-189) allowed the description of the exact structure of the MCU matrix domain ${ }^{82}$. This domain was shown to acquire a $\beta$-grasp-like fold and to bind $\mathrm{Mg}^{2+}$ and $\mathrm{Ca}^{2+}$ through a MCU-regulating acidic patch (MRAP) ${ }^{82}$. The disruption of cation binding via mutation of the MRAP sequence impairs MCU oligomerisation, reduces basal $\left[\mathrm{Ca}^{2+}\right]_{\mathrm{mt}}$ levels, and leads to significant dampening of mitochondrial $\mathrm{Ca}^{2+}$ uptake after agonist stimulation, highlighting the role of 
divalent cations in the regulation of MCU activity ${ }^{81}$. This has been proposed as a possible feedback mechanism of MCU regulation aimed at preventing excessive mitochondrial $\mathrm{Ca}^{2+}$ entry in conditions of elevated $\left[\mathrm{Ca}^{2+}\right]_{i}$.

Finally, a wide range of chemical modifications have been reported to target the thiol moiety of Cys residues in many proteins, enabling biological switching of structure and reactivity oxidation $^{83}$. One of these modifications, S-glutathionylation, was recently shown to occur in MCU protein as the result of oxidation at the evolutionarily conserved Cys- $97^{84}$. The S-glutathionylation has been demonstrated to promote a MCU conformational change, which increases oligomerisation ${ }^{84}$. In human pulmonary microvascular endothelial cells (HPMVECs), this enhances MCU activity and promotes increased mitochondrial $\mathrm{Ca}^{2+}$ entry both in basal conditions and upon agonist challenge, causing cellular bioenergetics crisis and higher sensitivity to cell death ${ }^{84}$.

Overall, the understanding of the mechanisms controlling $\mathrm{Ca}^{2+}$ entry in mitochondria has made a great step forward in the last few years, and new possibilities for effective modulation of MCU activity have been revealed. In this line, very recently, a systematic orthologous interspecies chemical screen based on the combination of an optimised yeast cell system and a mammalian mitochondria-based NCC library drug screen picked out and validated the first MCU-specific inhibitor molecule to be described: mitoxantrone ${ }^{85}$. Mitoxantrone has been utilised already in clinical practice for its antineoplastic action against non-Hodgkin's lymphomas and acute myeloid leukaemia ${ }^{86}$; however, the anti-tumour properties of this drug appear to rely on a different molecular moiety with respect to its anti-MCU activity, thus opening up the possibility for the chemical engineering of new lead compounds to specifically target MCU function. This is of outmost relevance for the design of novel potential therapeutic approaches to pathologies in which mitochondrial $\mathrm{Ca}^{2+}$ signalling dysfunction is involved ${ }^{17,87,88}$, including those characterised by primary MCU dysfunction due to mutations in its components ${ }^{50,52,53}$.

In conclusion, despite many of the molecular mechanisms refining MCU activity in the cell having been described, of which the most relevant are presented in this review, a number of other possibilities for the modulation of uniporter function may exist (at transcriptional and post-transcriptional levels), and additional efforts are needed from the scientific community to fully unravel the complexity of mitochondrial $\mathrm{Ca}^{2+}$ uptake regulation.

\section{Conclusions}

In the last few years, tremendous advances have been made in defining the molecular identity of the mitochondrial $\mathrm{Ca}^{2+}$ transport machinery. Most of the components of the MCU complex have been identified, and several cellular and in vivo models have been generated that helped to define the physiological relevance of mitochondrial $\mathrm{Ca}^{2+}$ uptake. Still, many issues remain obscure and need to be investigated. The entire spectrum of molecular mechanisms by which different cell types finely tune mitochondrial $\mathrm{Ca}^{2+}$ uptake appears to be related not only to the metabolic needs but also to the breadth of cellular activities modulated by organelle $\mathrm{Ca}^{2+}$ levels. We believe that the complete picture will emerge when at least three conceptual mechanisms are fully investigated, i.e. gene expression (the MCU and MICU1 isoforms show significant tissue-specific differences in expression), alternative splicing (as in the case of MICU1.1), and post-transcriptional and post-translational regulation (which, so far, has been only partially explored). We then need to explore the functional interplay between mitochondrial $\mathrm{Ca}^{2+}$ transport and other ion fluxes, such as $\mathrm{Na}^{+}$and $\mathrm{K}^{+}$, for which complexity and partial redundancy of transport mechanisms have been described but molecular definition still lags behind. Unravelling this cross-talk will greatly enhance our insight into the regulation of mitochondria, these fascinating organelles with pleiotropic effects on a cell's life and death.

\section{Abbreviations}

$\left[\mathrm{Ca}^{2+}\right]_{\mathrm{i}}$, intracellular $\mathrm{Ca}^{2+}$ concentration; $\left[\mathrm{Ca}^{2+}\right]_{\mathrm{mt}}$, mitochondrial $\mathrm{Ca}^{2+}$ concentration; CaM, calmodulin; $\mathrm{CaMK}$, calmodulin kinase; CREB, cyclic adenosine monophosphate response elementbinding protein; COX, cytochrome c oxidase; EMRE, essential mitochondrial $\mathrm{Ca}^{2+}$ uniporter regulator; ER, endoplasmic reticulum; IMM, inner mitochondrial membrane; IMS, intermembrane space; IP3R, inositol trisphosphate receptor; MCU, mitochondrial $\mathrm{Ca}^{2+}$ uniporter; MCUR1, mitochondrial $\mathrm{Ca}^{2+}$ uniporter regulator 1; MICU, mitochondrial $\mathrm{Ca}^{2+}$ uptake protein; miR, microRNA; MRAP, mitochondrial $\mathrm{Ca}^{2+}$ uniporter-regulating acidic patch; MTP, mitochondrial permeability transition; OXPHOS, oxidative phosphorylation; PAH, pulmonary arterial hypertension; PGC1 $\alpha 4$, peroxisome proliferator-activated receptor gamma coactivator 1 alpha 4; PTP, permeability transition pore; SR, sarcoplasmic reticulum; TMH, transmembrane helix

\section{Author contributions}

Giorgia Pallafacchina wrote the original draft, Sofia Zanin drew the figures, and Rosario Rizzuto revised the manuscript.

\section{Grant information}

This work was supported by grants to Rosario Rizzuto from the Italian Ministries of Health (Ricerca Finalizzata.) and of Education, University and Research (FIRB), the European Union (ERC mitoCalcium, no. 294777), the National Institutes of Health (grant \#1P01AG025532-01A1), the Italian Association for Cancer Research (AIRC IG18633), and Telethon-Italy (GGP16029). 
1. Berridge MJ: Inositol trisphosphate and calcium signalling. Nature. 1993; 361(6410): 315-25.

PubMed Abstract | Publisher Full Text

2. Berridge MJ, Lipp $P$, Bootman MD: The versatility and universality of calcium signalling. Nat Rev Mol Cell Biol. 2000; 1(1): 11-21.

PubMed Abstract | Publisher Full Text

3. Clapham DE: Calcium signaling. Cell. 2007; 131(6): 1047-58. PubMed Abstract | Publisher Full Text

4. Rizzuto R, De Stefani D, Raffaello A, et al:: Mitochondria as sensors and regulators of calcium signalling. Nat Rev Mol Cell Biol. 2012; 13(9): 566-78. PubMed Abstract | Publisher Full Text

5. Raffaello A, Mammucari C, Gherardi G, et al.: Calcium at the Center of Cell Signaling: Interplay between Endoplasmic Reticulum, Mitochondria, and Lysosomes. Trends Biochem Sci. 2016; 41(12): 1035-49. PubMed Abstract | Publisher Full Text | Free Full Text

6. Berridge MJ: The versatility and complexity of calcium signalling. Novartis Found Symp. 2001; 239: 52-64; discussion 64-7, 150-9. PubMed Abstract

7. Calì T, Brini M, Carafoli E: Regulation of Cell Calcium and Role of Plasma Membrane Calcium ATPases. Int Rev Cell Mol Biol. 2017; 332: 259-96. PubMed Abstract | Publisher Full Text

8. Vandecaetsbeek I, Vangheluwe $\mathrm{P}$, Raeymaekers $\mathrm{L}$, et al.: The $\mathrm{Ca}^{2+}$ pumps of the endoplasmic reticulum and Golgi apparatus. Cold Spring Harb Perspect Biol. 2011; 3(5): pii: a004184

PubMed Abstract | Publisher Full Text | Free Full Text

9. Brini $\mathrm{M}$, Calì $\mathrm{T}$, Ottolini $\mathrm{D}$, et al.: Calcium pumps: why so many? Compr Physiol. 2012; 2(2): 1045-60.

PubMed Abstract | Publisher Full Text

10. Pinton P, Pozzan T, Rizzuto R: The Golgi apparatus is an inositol 1,4,5trisphosphate-sensitive $\mathrm{Ca}^{2+}$ store, with functional properties distinct from those of the endoplasmic reticulum. EMBO J. 1998; 17(18): 5298-308. PubMed Abstract | Publisher Full Text | Free Full Text

11. F Calcraft PJ, Ruas M, Pan Z, et al:: NAADP mobilizes calcium from acidic organelles through two-pore channels. Nature. 2009; 459(7246): 596-600. PubMed Abstract | Publisher Full Text | Free Full Text | F1000 Recommendation

12. Deluca HF, Engstrom GW: Calcium uptake by rat kidney mitochondria. Proc Natl Acad Sci U S A. 1961; 47: 1744-50.

PubMed Abstract | Publisher Full Text | Free Full Text

13. Vasington FD, Murphy JV: Ca ion uptake by rat kidney mitochondria and its dependence on respiration and phosphorylation. J Biol Chem. 1962; 237: $2670-7$.

PubMed Abstract

14. Carafoli E, Rossi CS, Lehninger AL: Cation and Anion Balance During Active Accumulation of $\mathbf{C a + +}$ and $\mathbf{M g}++$ by Isolated Mitochondria. J Biol Chem. 1964; 239: 3055-61.

PubMed Abstract

15. Mitchell $\mathrm{P}$ : Coupling of phosphorylation to electron and hydrogen transfer by a chemi-osmotic type of mechanism. Nature. 1961; 191: 144-8. PubMed Abstract | Publisher Full Text

16. Penna E, Espino J, De Stefani D, et al.: The MCU complex in cell death. Cell Calcium. 2018; 69: 73-80.

PubMed Abstract | Publisher Full Text

17. Granatiero V, De Stefani D, Rizzuto R: Mitochondrial Calcium Handling in Physiology and Disease. Adv Exp Med Biol. 2017; 982: 25-47. PubMed Abstract | Publisher Full Text

18. Marchi S, Patergnani S, Missiroli S, et al:: Mitochondrial and endoplasmic reticulum calcium homeostasis and cell death. Cell Calcium. 2018; 69: 62-72. PubMed Abstract | Publisher Full Text

19. Giacomello M, Drago I, Pizzo $\mathrm{P}$, et al:: Mitochondrial $\mathrm{Ca}^{2+}$ as a key regulator of cell life and death. Cell Death Differ. 2007; 14(7): 1267-74. PubMed Abstract | Publisher Full Text

20. F Kirichok $Y$, Krapivinsky G, Clapham DE: The mitochondrial calcium uniporter is a highly selective ion channel. Nature. 2004; 427(6972): 360-4. PubMed Abstract | Publisher Full Text | F1000 Recommendation

21. F Perocchi F, Gohil VM, Girgis HS, et al:: MICU1 encodes a mitochondrial EF hand protein required for $\mathrm{Ca}^{2+}$ uptake. Nature. 2010; 467(7313): 291-6. PubMed Abstract | Publisher Full Text | Free Full Text | F1000 Recommendation

22. $\mathrm{F}$ Baughman JM, Perocchi F, Girgis HS, et al:: Integrative genomics identifies $\mathrm{MCU}$ as an essential component of the mitochondrial calcium uniporter. Nature. 2011; 476(7360): 341-5.

PubMed Abstract | Publisher Full Text | Free Full Text | F1000 Recommendation

23. F De Stefani D, Raffaello A, Teardo E, et al:: A forty-kilodalton protein of the inner membrane is the mitochondrial calcium uniporter. Nature. 2011; 476(7360): $336-40$

PubMed Abstract | Publisher Full Text | Free Full Text | F1000 Recommendation

24. $\mathrm{F}$ Baradaran $\mathrm{R}$, Wang $\mathrm{C}$, Siliciano $\mathrm{AF}$, et al.: Cryo-EM structures of fungal and metazoan mitochondrial calcium uniporters. Nature. 2018; 559(7715): 580-4. PubMed Abstract | Publisher Full Text | F1000 Recommendation

25. Raffaello A, De Stefani D, Sabbadin D, et al.: The mitochondrial calcium uniporter is a multimer that can include a dominant-negative pore-forming subunit. EMBO J. 2013; 32(17): 2362-76.

PubMed Abstract | Publisher Full Text | Free Full Text

26. F Yoo J, Wu M, Yin Y, et al:: Cryo-EM structure of a mitochondrial calcium uniporter. Science. 2018; 361(6401): 506-11.

PubMed Abstract | Publisher Full Text | Free Full Text | F1000 Recommendation

27. F Nguyen NX, Armache JP, Lee $\mathrm{C}$, et al:: Cryo-EM structure of a fungal mitochondrial calcium uniporter. Nature. 2018; 559(7715): 570-4. PubMed Abstract | Publisher Full Text | Free Full Text | F1000 Recommendation

28. F Fan C, Fan M, Orlando BJ, et al:: X-ray and cryo-EM structures of the mitochondrial calcium uniporter. Nature. 2018; 559(7715): 575-9. PubMed Abstract | Publisher Full Text | F1000 Recommendation

29. Oxenoid K, Dong $\mathrm{Y}, \mathrm{Cao} \mathrm{C}$, et al:: Architecture of the mitochondrial calcium uniporter. Nature. 2016; 533(7602): 269-73.

PubMed Abstract | Publisher Full Text | Free Full Text

30. Chiurillo MA, Lander N, Bertolini MS, et al.: Different Roles of Mitochondrial Calcium Uniporter Complex Subunits in Growth and Infectivity of Trypanosoma cruzi. MBio. 2017; 8(3): pii: e00574-17. PubMed Abstract | Publisher Full Text | Free Full Text

31. Huang G, Docampo R: The Mitochondrial $\mathrm{Ca}^{2+}$ Uniporter Complex (MCUC) of Trypanosoma brucei Is a Hetero-oligomer That Contains Novel Subunits Essential for $\mathrm{Ca}^{2+}$ Uptake. MBio. 2018; 9(5): pii: e01700-18.

PubMed Abstract | Publisher Full Text | Free Full Text

32. Fieni F, Lee SB, Jan YN, et al.: Activity of the mitochondrial calcium uniporter varies greatly between tissues. Nat Commun. 2012; 3: 1317. PubMed Abstract | Publisher Full Text | Free Full Text

33. Barth E, Stämmler G, Speiser B, et al.: Ultrastructural quantitation of mitochondria and myofilaments in cardiac muscle from 10 different animal species including man. J Mol Cell Cardiol. 1992; 24(7): 669-81. PubMed Abstract | Publisher Full Text

34. Pan X, Liu J, Nguyen T, et al.: The physiological role of mitochondrial calcium revealed by mice lacking the mitochondrial calcium uniporter. Nat Cell Biol. 2013; 15(12): 1464-72.

PubMed Abstract | Publisher Full Text | Free Full Text

35. Murphy E, Pan X, Nguyen T, et al:: Unresolved questions from the analysis of mice lacking MCU expression. Biochem Biophys Res Commun. 2014; 449(4): 384-5.

PubMed Abstract | Publisher Full Text | Free Full Text

36. Kwong JQ, Lu X, Correll RN, et al:: The Mitochondrial Calcium Uniporter Selectively Matches Metabolic Output to Acute Contractile Stress in the Heart. Cell Rep. 2015; 12(1): 15-22.

PubMed Abstract | Publisher Full Text | Free Full Text

37. Luongo TS, Lambert JP, Yuan A, et al.: The Mitochondrial Calcium Uniporter Matches Energetic Supply with Cardiac Workload during Stress and Modulates Permeability Transition. Cell Rep. 2015; 12(1): 23-34. PubMed Abstract | Publisher Full Text | Free Full Text

38. Wu Y, Rasmussen TP, Koval OM, et al:: The mitochondrial uniporter controls fight or flight heart rate increases. Nat Commun. 2015; 6: 6081. PubMed Abstract | Publisher Full Text | Free Full Text

39. Rasmussen TP, Wu Y, Joiner ML, et al:: Inhibition of MCU forces extramitochondrial adaptations governing physiological and pathological stress responses in heart. Proc Natl Acad Sci U S A. 2015; 112(29): 9129-34. PubMed Abstract | Publisher Full Text | Free Full Text

40. Nichols M, Elustondo PA, Warford J, et al:: Global ablation of the mitochondrial calcium uniporter increases glycolysis in cortical neurons subjected to energetic stressors. J Cereb Blood Flow Metab. 2017; 37(8): 3027-41. PubMed Abstract | Publisher Full Text | Free Full Text

41. Nichols M, Pavlov EV, Robertson GS: Tamoxifen-induced knockdown of the mitochondrial calcium uniporter in Thy1-expressing neurons protects mice from hypoxic/ischemic brain injury. Cell Death Dis. 2018; 9(6): 606. PubMed Abstract | Publisher Full Text | Free Full Text

42. Wang J, Wilhelmsson H, Graff C, et al:: Dilated cardiomyopathy and atrioventricular conduction blocks induced by heart-specific inactivation of mitochondrial DNA gene expression. Nat Genet. 1999; 21(1): 133-7. PubMed Abstract | Publisher Full Text

43. Sommakia S, Houlihan PR, Deane SS, et al: Mitochondrial cardiomyopathies feature increased uptake and diminished efflux of mitochondrial calcium. J Mol Cell Cardiol. 2017; 113: 22-32. PubMed Abstract | Publisher Full Text | Free Full Text

44. Mammucari C, Gherardi G, Zamparo I, et al:: The mitochondrial calcium uniporter controls skeletal muscle trophism in vivo. Cell Rep. 2015; 10(8): 1269-79.

PubMed Abstract | Publisher Full Text | Free Full Text

45. Gherardi G, Nogara L, Ciciliot S, et al:: Loss of mitochondrial calcium uniporter rewires skeletal muscle metabolism and substrate preference. Cell Death Differ. 
2018

PubMed Abstract | Publisher Full Text

46. Mallilankaraman K, Doonan P, Cárdenas C, et al: MICU1 is an essential gatekeeper for $\mathrm{MCU}$-mediated mitochondrial $\mathrm{Ca}^{2+}$ uptake that regulates cell survival. Cell. 2012; 151(3): 630-44.

PubMed Abstract | Publisher Full Text | Free Full Text

47. Csordás G, Golenár T, Seifert EL, et al:: MICU1 controls both the threshold and cooperative activation of the mitochondrial $\mathrm{Ca}^{2+}$ uniporter. Cell Metab. 2013; 17(6): $976-87$

PubMed Abstract | Publisher Full Text | Free Full Text

48. F Liu JC, Liu J, Holmström KM, et al:: MICU1 Serves as a Molecula Gatekeeper to Prevent In Vivo Mitochondrial Calcium Overload. Cell Rep. 2016; 16(6): 1561-73.

PubMed Abstract | Publisher Full Text | Free Full Text | F1000 Recommendation

49. F Antony AN, Paillard M, Moffat C, et al:: MICU1 regulation of mitochondrial $\mathrm{Ca}^{2+}$ uptake dictates survival and tissue regeneration. Nat Commun. 2016; 7 : 10955.

PubMed Abstract | Publisher Full Text | Free Full Text | F1000 Recommendation

50. Logan CV, Szabadkai G, Sharpe JA, et al.: Loss-of-function mutations in MICU1 cause a brain and muscle disorder linked to primary alterations in mitochondrial calcium signaling. Nat Genet. 2014; 46(2): 188-93. PubMed Abstract | Publisher Full Text

51. F Kamer KJ, Sancak Y, Fomina $Y$, et al: MICU1 imparts the mitochondrial uniporter with the ability to discriminate between $\mathrm{Ca}^{2+}$ and $\mathrm{Mn}^{2+}$ Proc Natl Acad SciU S A. 2018; 115(34): E7960-E7969.

PubMed Abstract | Publisher Full Text | Free Full Text | F1000 Recommendation

52. Lewis-Smith D, Kamer KJ, Griffin $\mathrm{H}$, et al:: Homozygous deletion in MICU1 presenting with fatigue and lethargy in childhood. Neurol Genet. 2016; 2(2): e59.

PubMed Abstract | Publisher Full Text | Free Full Text

53. Musa S, Eyaid W, Kamer K, et al:: A Middle Eastern Founder Mutation Expands the Genotypic and Phenotypic Spectrum of Mitochondrial MICU1 Deficiency: A Report of 13 Patients. JIMD Rep. 2018; 1-5. PubMed Abstract | Publisher Full Text

54. Plovanich M, Bogorad RL, Sancak Y, et al:: MICU2, a paralog of MICU1, resides within the mitochondrial uniporter complex to regulate calcium handling. PLoS One. 2013; 8(2): e55785.

PubMed Abstract | Publisher Full Text | Free Full Text

55. Patron M, Granatiero V, Espino J, et al.: MICU3 is a tissue-specific enhancer of mitochondrial calcium uptake. Cell Death Differ. 2018. PubMed Abstract | Publisher Full Text | Free Full Text

56. Patron M, Checchetto V, Raffaello A, et al:: MICU1 and MICU2 finely tune the mitochondrial $\mathrm{Ca}^{2+}$ uniporter by exerting opposite effects on MCU activity. Mol Cell. 2014; 53(5): 726-37.

PubMed Abstract | Publisher Full Text | Free Full Text

57. F Kamer KJ, Grabarek Z, Mootha VK: High-affinity cooperative $\mathrm{Ca}^{2+}$ binding by MICU1-MICU2 serves as an on-off switch for the uniporter.. EMBO Rep. 2017; 18(8): 1397-411.

PubMed Abstract | Publisher Full Text | Free Full Text | F1000 Recommendation

58. F Payne R, Hoff H, Roskowski A, et al: MICU2 Restricts Spatial Crosstalk between Ins $\mathrm{P}_{3} \mathrm{R}$ and MCU Channels by Regulating Threshold and Gain of MICU1-Mediated Inhibition and Activation of MCU. Cell Rep. 2017; 21(11): 3141-54.

PubMed Abstract | Publisher Full Text | Free Full Text | F1000 Recommendation

59. F Paillard M, Csordás G, Szanda G, et al.: Tissue-Specific Mitochondrial Decoding of Cytoplasmic $\mathrm{Ca}^{2+}$ Signals Is Controlled by the Stoichiometry of MICU1/2 and MCU. Cell Rep. 2017; 18(10): 2291-300.

PubMed Abstract | Publisher Full Text | Free Full Text | F1000 Recommendation

60. Vecellio Reane D, Vallese F, Checchetto V, et al.: A MICU1 Splice Variant Confers High Sensitivity to the Mitochondrial $\mathrm{Ca}^{2+}$ Uptake Machinery of Skeletal Muscle. Mol Cell. 2016; 64(4): 760-73.

PubMed Abstract | Publisher Full Tex

61. Sancak Y, Markhard AL, Kitami T, et al.: EMRE is an essential component of the mitochondrial calcium uniporter complex. Science. 2013; 342(6164): 1379-82. PubMed Abstract | Publisher Full Text | Free Full Text

62. F Vais $\mathrm{H}$, Mallilankaraman $\mathrm{K}, \mathrm{Mak} \mathrm{DD}$, et al:: EMRE Is a Matrix $\mathrm{Ca}^{2+}$ Sensor that Governs Gatekeeping of the Mitochondrial $\mathbf{C a}^{2+}$ Uniporter. Cell Rep. 2016; 14(3): 403-10.

PubMed Abstract | Publisher Full Text | Free Full Text | F1000 Recommendation

63. F Tsai MF, Phillips CB, Ranaghan M, et al: Dual functions of a smal regulatory subunit in the mitochondrial calcium uniporter complex. eLife. 2016; 5: pii: e15545.

PubMed Abstract | Publisher Full Text | Free Full Text | F1000 Recommendation

64. Yamamoto T, Yamagoshi R, Harada K, et al:: Analysis of the structure and function of EMRE in a yeast expression system. Biochim Biophys Acta. 2016 1857(6): 831-9.

PubMed Abstract | Publisher Full Text

65. König T, Tröder SE, Bakka K, et al:: The m-AAA Protease Associated with Neurodegeneration Limits MCU Activity in Mitochondria. Mol Cell. 2016; 64(1):
$148-62$

PubMed Abstract | Publisher Full Tex

66. Patron M, Sprenger HG, Langer T: m-AAA proteases, mitochondrial calcium homeostasis and neurodegeneration. Cell Res. 2018; 28(3): 296-306. PubMed Abstract | Publisher Full Text | Free Full Text

67. Mallilankaraman K, Cárdenas $\mathrm{C}$, Doonan PJ, et al.: MCUR1 is an essential component of mitochondrial $\mathrm{Ca}^{2+}$ uptake that regulates cellular metabolism. Nat Cell Biol. 2012: 14(12): 1336-43.

PubMed Abstract | Publisher Full Text | Free Full Text

68. Tomar D, Dong Z, Shanmughapriya S, et al:: MCUR1 Is a Scaffold Factor for the MCU Complex Function and Promotes Mitochondrial Bioenergetics. Cell Rep. 2016; 15(8): 1673-85.

PubMed Abstract | Publisher Full Text | Free Full Text

69. Paupe V, Prudent J, Dassa EP, et al:: CCDC90A (MCUR1) is a cytochrome c oxidase assembly factor and not a regulator of the mitochondrial calcium uniporter. Cell Metab. 2015; 21(1): 109-16.

PubMed Abstract | Publisher Full Text

70. F Sickmann A, Reinders J, Wagner $\mathrm{Y}$, et al:: The proteome of Saccharomyces cerevisiae mitochondria. Proc Natl Acad Sci U S A. 2003; 100(23): 13207-12. PubMed Abstract | Publisher Full Text | Free Full Text | F1000 Recommendation

71. Vais H, Tanis JE, Müller M, et al:: MCUR1, CCDC90A, Is a Regulator of the Mitochondrial Calcium Uniporter. Cell Metab. 2015; 22(4): 533-5. PubMed Abstract | Publisher Full Text | Free Full Text

72. Chaudhuri D, Artiga DJ, Abiria SA, et al.: Mitochondrial calcium uniporter regulator 1 (MCUR1) regulates the calcium threshold for the mitochondrial permeability transition. Proc Natl Acad Sci U S A. 2016; 113(13): E1872-80. PubMed Abstract | Publisher Full Text | Free Full Text

73. Qu J, Tan YW, Hagenston AM, et al.: Mitochondrial calcium uniporter Mcu controls excitotoxicity and is transcriptionally repressed by neuroprotective nuclear calcium signals. Nat Commun. 2013; 4: 2034. PubMed Abstract | Publisher Full Text | Free Full Text

74. Zhang SJ, Zou M, Lu L, et al.: Nuclear calcium signaling controls expression of a large gene pool: identification of a gene program for acquired neuroprotection induced by synaptic activity. PLoS Genet. 2009; 5(8): e1000604.

PubMed Abstract | Publisher Full Text | Free Full Text

75. F Shanmughapriya S, Rajan S, Hoffman NE, et al:: $\mathrm{Ca}^{2+}$ signals regulate mitochondrial metabolism by stimulating CREB-mediated expression of the mitochondrial $\mathrm{Ca}^{2+}$ uniporter gene MCU. Sci Signal. 2015; 8(366): ra23. PubMed Abstract | Publisher Full Text | Free Full Text | F1000 Recommendation

76. Marchi S, Lupini L, Patergnani S, et al.: Downregulation of the mitochondrial calcium uniporter by cancer-related miR-25. Curr Biol. 2013; 23(1): 58-63. PubMed Abstract | Publisher Full Text | Free Full Text

77. Yu C, Wang Y, Peng J, et al:: Mitochondrial calcium uniporter as a target of microRNA-340 and promoter of metastasis via enhancing the Warburg effect. Oncotarget. 2017; 8(48): 83831-44. PubMed Abstract | Publisher Full Text | Free Full Text

78. Hong Z, Chen KH, DasGupta A, et al.: MicroRNA-138 and MicroRNA-25 Downregulate Mitochondrial Calcium Uniporter, Causing the Pulmonary Arterial Hypertension Cancer Phenotype. Am J Respir Crit Care Med. 2017; 195(4): 515-29.

PubMed Abstract | Publisher Full Text | Free Full Text

79. Pan L, Huang BJ, Ma XE, et al.: MiR-25 protects cardiomyocytes against oxidative damage by targeting the mitochondrial calcium uniporter. Int $\mathrm{J} \mathrm{Mol}$ Sci. 2015; 16(3): 5420-33.

PubMed Abstract | Publisher Full Text | Free Full Text

80. Zaglia T, Ceriotti $\mathrm{P}$, Campo A, et al: Content of mitochondrial calcium uniporter (MCU) in cardiomyocytes is regulated by microRNA-1 in physiologic and pathologic hypertrophy. Proc Natl Acad Sci U S A. 2017; 114(43): E9006-E9015. PubMed Abstract | Publisher Full Text | Free Full Text

81. O-Uchi J, Jhun BS, Xu S, et al.: Adrenergic signaling regulates mitochondrial $\mathrm{Ca}^{2+}$ uptake through Pyk2-dependent tyrosine phosphorylation of the mitochondrial $\mathrm{Ca}^{2+}$ uniporter. Antioxid Redox Signal. 2014; 21(6): 863-79. PubMed Abstract | Publisher Full Text | Free Full Text

82. F Lee SK, Shanmughapriya S, Mok MCY, et al:: Structural Insights into Mitochondrial Calcium Uniporter Regulation by Divalent Cations. Cell Chem Biol. 2016; 23(9): 1157-69.

PubMed Abstract | Publisher Full Text | Free Full Text | F1000 Recommendation

83. Wani R, Nagata A, Murray BW: Protein redox chemistry: Post-translational cysteine modifications that regulate signal transduction and drug pharmacology. Front Pharmacol. 2014; 5: 224 PubMed Abstract | Publisher Full Text | Free Full Text

84. $\mathrm{F}$ Dong Z, Shanmughapriya S, Tomar D, et al:: Mitochondrial $\mathrm{Ca}^{2+}$ Uniporter Is a Mitochondrial Luminal Redox Sensor that Augments MCU Channel Activity. Mol Cell. 2017; 65(6): 1014-1028.e7

PubMed Abstract | Publisher Full Text | Free Full Text | F1000 Recommendation

85. F Arduino DM, Wettmarshausen J, Vais $\mathrm{H}$, et al:: Systematic Identification of MCU Modulators by Orthogonal Interspecies Chemical Screening. Mol Cell. 2017; 67(4): 711-723.e7.

PubMed Abstract | Publisher Full Text | Free Full Text | F1000 Recommendation 
86. Evison BJ, Sleebs BE, Watson KG, et al:: Mitoxantrone, More than Just Another Topoisomerase II Poison. Med Res Rev. 2016; 36(2): 248-99. PubMed Abstract | Publisher Full Text

87. Mammucari C, Gherardi G, Rizzuto R: Structure, Activity Regulation, and Role of the Mitochondrial Calcium Uniporter in Health and Disease. Front Oncol. 2017;
7: 139.

PubMed Abstract | Publisher Full Text | Free Full Text

88. Calì T, Ottolini D, Brini M: Mitochondrial $\mathrm{Ca}^{2+}$ and neurodegeneration. Cell Calcium. 2012; 52(1): 73-85.

PubMed Abstract | Publisher Full Text | Free Full Text 


\section{Open Peer Review}

\section{Current Peer Review Status:}

\section{Editorial Note on the Review Process}

Faculty Reviews are review articles written by the prestigious Members of Faculty Opinions. The articles are commissioned and peer reviewed before publication to ensure that the final, published version is comprehensive and accessible. The reviewers who approved the final version are listed with their names and affiliations.

\section{The reviewers who approved this article are:}

\section{Version 1}

\section{Dipayan Chaudhuri}

Nora Eccles Harrison Cardiovascular Research and Training Institute, Cardiology Division, Department of Internal Medicine, University of Utah, Salt Lake City, UT, USA

Competing Interests: No competing interests were disclosed.

\section{Evgeny V Pavlov}

Department of Basic Sciences, College of Dentistry, New York University, 345 East 24th Street, New York, NY, 10010, USA

Competing Interests: No competing interests were disclosed.

\section{Israel Sekler}

Department of Physiology and Cell Biology, Faculty of Health Science, Ben-Gurion University, BeerSheva, Israel

Competing Interests: No competing interests were disclosed.

\section{Roberto Docampo}

Center for Tropical and Emerging Global Diseases, University of Georgia, Athens, GA, 30602, USA

Competing Interests: No competing interests were disclosed. 
The benefits of publishing with F1000Research:

- Your article is published within days, with no editorial bias

- You can publish traditional articles, null/negative results, case reports, data notes and more

- The peer review process is transparent and collaborative

- Your article is indexed in PubMed after passing peer review

- Dedicated customer support at every stage

For pre-submission enquiries, contact research@f1000.com 